\title{
CDK12 Loss of Function Mutation
}

National Cancer Institute

\section{Source}

National Cancer Institute. CDK12 Loss of Function Mutation. NCI Thesaurus. Code C158676.

A change in the nucleotide sequence of the CDK12 gene that either inhibits expression or results in the translation of an inactive cyclin-dependent kinase 12 protein. 